\title{
Recovery Plan for Tar Spot of Corn, Caused by Phyllachora maydis
}

Camila Rocco da Silva, ${ }^{1}$ Jill Check, ${ }^{2}$ Joshua S. MacCready, ${ }^{2}$ Amos E. Alakonya, ${ }^{3}$ Robert Beiriger, ${ }^{4}$ Kaitlyn M. Bissonnette, ${ }^{5}$ Alyssa Collins, ${ }^{6}$ C. D. Cruz, ${ }^{1}$ Paul D. Esker, ${ }^{6}$ Stephen B. Goodwin, ${ }^{7}$ Dean Malvick, ${ }^{8}$ Daren S. Mueller, ${ }^{9}$ Pierce Paul, ${ }^{10}$ Richard Raid, ${ }^{4}$ Alison E. Robertson, ${ }^{9}$ Emily Roggenkamp, ${ }^{2}$ Tiffanna J. Ross, ${ }^{1}$ Raksha Singh, ${ }^{7}$ Damon L. Smith, ${ }^{11}$ Albert U. Tenuta, ${ }^{12}$ Martin I. Chilvers, ${ }^{2}$ and Darcy E. P. Telenko ${ }^{1,+}$

${ }^{1}$ Department of Botany and Plant Pathology, Purdue University, West Lafayette, IN 47907, U.S.A.

${ }^{2}$ Department of Plant, Soil and Microbial Sciences, Michigan State University, East Lansing, MI 48824, U.S.A.

${ }^{3}$ International Maize and Wheat Improvement Center (CIMMYT), Carretera MéxicoVeracruz Km. 45, El Batán, Texcoco, C.P. 56237, México

${ }^{4}$ Everglades Research and Education Center, University of Florida, Belle Glade, FL 33430, U.S.A.

${ }^{5}$ Division of Plant Sciences, University of Missouri-Columbia, Columbia, MO 65211, U.S.A.

${ }^{6}$ Department of Plant Pathology and Environmental Microbiology, Penn State University, University Park, PA 16802, U.S.A.

${ }^{7}$ Crop Production and Pest Control Research Unit, U.S. Department of AgricultureAgricultural Research Service (USDA-ARS), Purdue University, West Lafayette, IN 47907, U.S.A.

${ }^{8}$ Department of Plant Pathology, University of Minnesota, St. Paul, MN 55108, U.S.A.

${ }^{9}$ Department of Plant Pathology and Microbiology, lowa State University, Ames, IA 50011, U.S.A.

${ }^{10}$ Department of Plant Pathology, The Ohio State University, 1680 Madison Ave., Wooster, OH 44691, U.S.A.

${ }^{11}$ Department of Plant Pathology, University of Wisconsin-Madison, Madison, WI 53706, U.S.A.

${ }^{12}$ Ontario Ministry of Agriculture, Food and Rural Affairs, University of Guelph Ridgetown Campus, Ridgetown, ON. NOP 2C0, Canada

Accepted for publication 3 July 2021.

C. Rocco da Silva, J. Check, J. S. MacCready, and D. E. P. Telenko contributed equally.

${ }^{\dagger}$ Corresponding author: D. E. P. Telenko; dtelenko@purdue.edu

This article is in the public domain and not copyrightable.

It may be freely reprinted with customary crediting of the source.

The American Phytopathological Society, 2021. 
Table of Contents

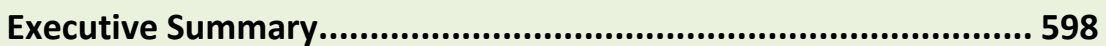

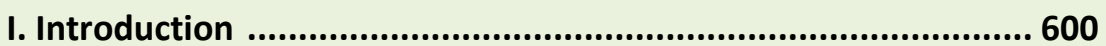

II. Disease Cycle and Symptom Development .................................60 600

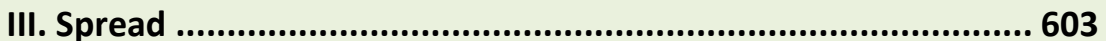

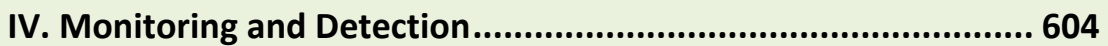

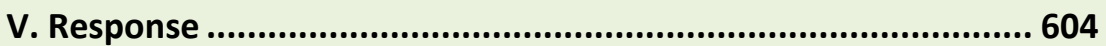

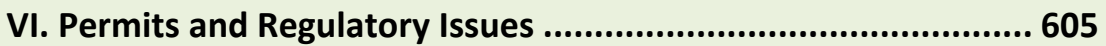

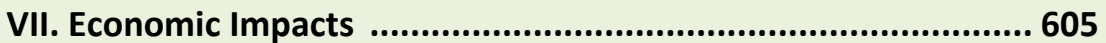

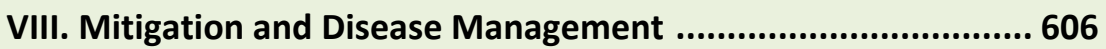

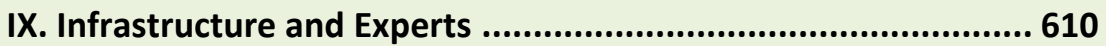

$X$. Research, Extension, and Education Priorities .......................... 611

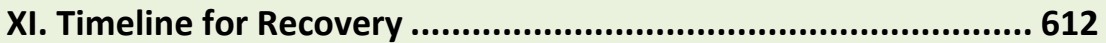

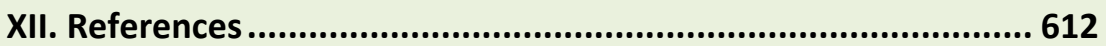

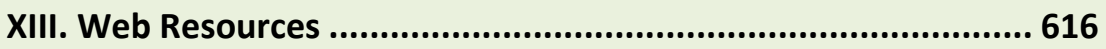

Keywords: maize, Monographella maydis

Funding: We acknowledge the funding and support from the National Plant Disease Recovery System (NPDRS) of the USDA-Agricultural Research Service through Dr. Tim Widmer. Additional funding provided by Corn Marketing Program of Michigan, Foundation for Food and Agriculture Research - Rapid Outcomes from Agricultural Research (FFAR-ROAR), and Indiana Corn Marketing Council. 
The outlined recovery plan is one of several disease-specific documents produced as part of the National Plant Disease Recovery System (NPDRS) called for in Homeland Security Presidential Directive Number 9 (HSPD-9). The purpose of the NPDRS is to ensure that the tools, infrastructure, communication networks, and capacity required to mitigate the impact of high-consequence plant disease outbreaks are such that a reasonable level of crop production is maintained.

Each disease-specific plan is intended to provide a brief primer on the disease, assess the status of critical recovery components, and identify disease management research, Extension, and education needs. As such, these documents are not intended to be stand-alone documents that address all of the many and varied aspects of a plant disease outbreak, or all of the decisions that must be made and actions taken to achieve effective response and recovery. They are, however, documents that will help the USDA guide additional efforts directed toward plant disease recovery.

\section{Executive Summary}

Tar spot is a foliar disease of corn threatening production across the Americas. The disease was first documented in Mexico in 1904 and is now present in 15 additional countries throughout Central and South America, as well as the Caribbean. Researchers and growers in these corn-producing regions consider tar spot to be a disease complex caused by multiple fungal pathogens. When environmental conditions are conducive for infection, these regions have experienced yield losses as great as $100 \%$. In 2015, tar spot was detected in the United States for the first time in Illinois and Indiana. Since that time tar spot has spread across the Midwestern U.S. corn-growing region, and the disease has been found in Florida, Illinois, Indiana, Iowa, Michigan, Minnesota, Missouri, Ohio, Pennsylvania, and Wisconsin. In 2020, tar spot was also detected in southwest Ontario, Canada (Fig. 1). Losses in the United States due to tar spot totaled

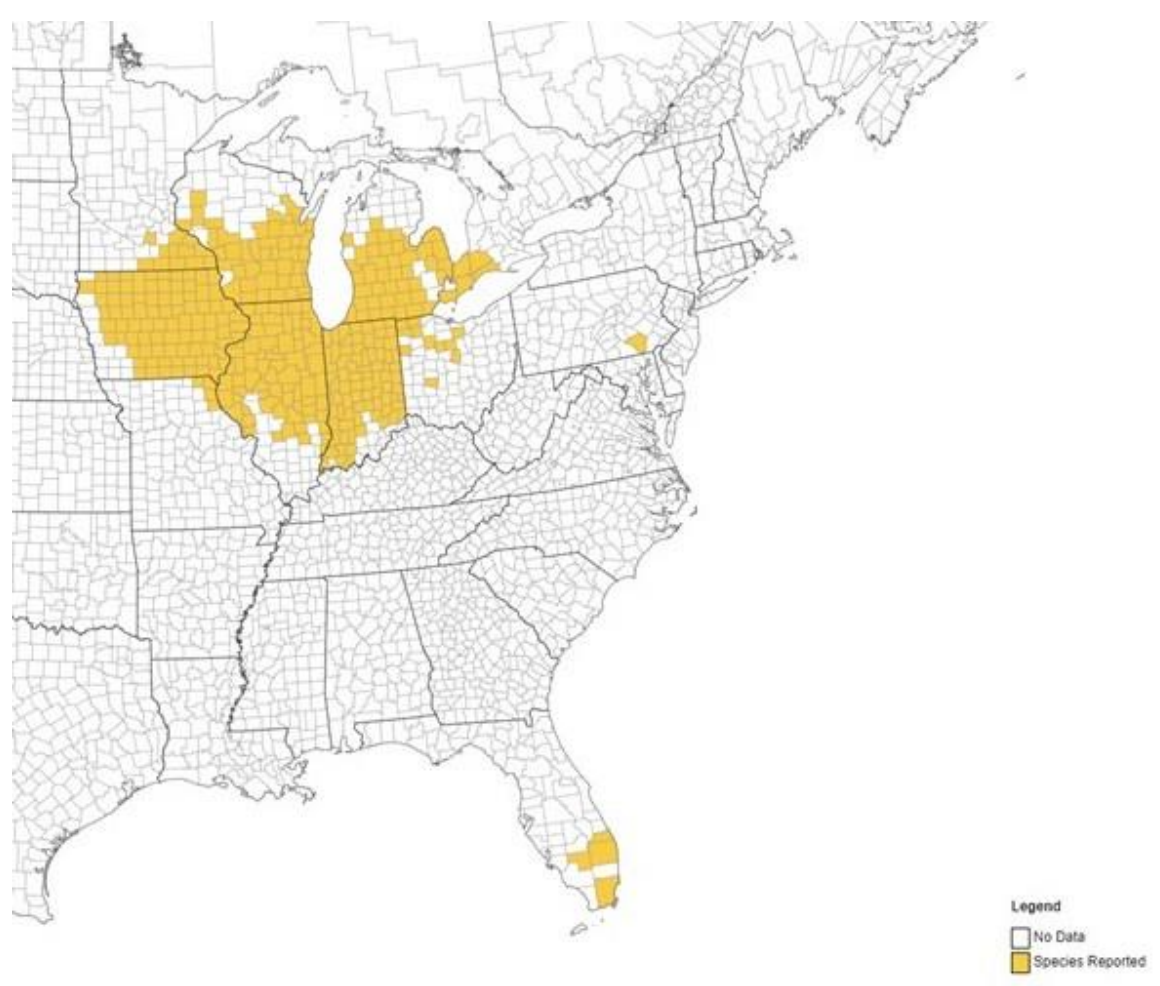

FIGURE 1

Known distribution of tar spot in the United States and Canada as of December 2020, indicated by yellow color. Source: https://corn.ipmpipe.org/tarspot/. 
an estimated 241 million bushels from 2018 to 2020 . With the potential to continue to spread across the U.S. corn-growing region, much greater losses could result when environmental conditions are conducive.

In the United States tar spot appears to be caused by one fungal pathogen, Phyllachora maydis, an obligate fungal pathogen. Due to its obligate nature, it cannot be cultured on media, making observation and experimentation in the laboratory difficult. The lifecycle of P. maydis is still not well understood. However, it has been demonstrated that this fungus can overwinter on corn residue in the northern United States. Inoculum is primarily spores (ascospores), which are disseminated over short distances via rain splash or air currents, and likely up to thousands of meters via wind. The pathogen may also spread by movement of infested plant material. There is no evidence that $P$. maydis can be spread via infected or infested seeds or has any alternate hosts. $P$. maydis reduces yield by inhibiting the plant's ability to photosynthesize by developing lesions that cover the plant leaf surface and reduce green tissue area. Tar spot infection can be diagnosed by evaluation of unique symptoms and signs. Signs and symptoms of infection include black, glossy, raised stroma on the leaf surface, which may or may not be surrounded by a necrotic lesion often referred to as a fisheye lesion. Stroma can be dissected to reveal the fungus's sexual reproductive structures, perithecia, which can also aid the diagnosis. Diagnosis is required for monitoring of disease spread across North America, which is tracked by university plant pathology Extension personnel and reported in real time to https://corn.ipmpipe.org/.

The establishment of tar spot and its recurrence and spread across multiple states and years make eradication in the United States and now Ontario impossible. Instead, efforts have been focused on understanding how to successfully manage this disease. The current understanding of tar spot management is largely based on the research conducted in Central and South America and the Caribbean, and it will need to be reinvestigated to produce suggestions for growers in the United States and Canada. Currently, all corn hybrids are partially susceptible to infection by P. maydis but vary in their level of resistance. A single source of genetic resistance to tar spot has been identified ( $q$ Rtsc8-1), but fully resistant hybrids have yet to be developed. Chemical control is effective with multiple popular mixed-modes-of-action fungicides providing protection against infection. However, understanding optimal fungicide application timing will be crucial in limiting disease severity. Manipulating the microclimate within the corn canopy via managing irrigation inputs and plant density has also demonstrated potential for disease control. Continuing efforts to understand pathogen biology, epidemiology, and management strategies are needed to help reduce the impact of tar spot, and the authors recommend actions that include the following:

- Continue to collaborate with diagnostic laboratories to document the occurrence and spread of P. maydis across North America.

- Characterize resistance levels of inbred lines and commercial hybrids, and identify sources of genetic resistance to tar spot.

- Develop disease management strategies by evaluating weather-based prediction and syndromic models, effects of irrigation, chemical and biological fungicide efficacy, and other cultural practices.

- Elucidate aspects of pathogen biology, epidemiology, and ecology, such as the disease cycle, inoculum survival, spore dispersal both within the plant canopy and at meso- and macro-scale, and general spatiotemporal patterns associated with epidemics.

- Continue to create and distribute educational and Extension resources for disease identification and management in areas currently affected by tar spot and in unaffected areas that have the potential for new outbreaks. 


\section{Introduction}

Phyllachora maydis Maubl. is the causal agent of tar spot on corn (Bajet et al. 1994; Hock et al. 1989; Maublanc 1904; Parbery 1963). P. maydis is an obligate pathogen, which is an organism that must exploit its host plant to complete its life cycle, and cannot be cultured on laboratory media. Tar spot is one of the most important foliar diseases of corn (Zea mays L.) in the tropical and subtropical regions of Central America, South America, and the Caribbean, causing significant yield losses when weather conditions (moderately cool and humid) favor disease development (Bajet et al. 1994; Cao et al. 2017; Maublanc 1904). Tar spot outbreaks that occur early in the growing season may cause up to $75 \%$ yield losses and reduce the quality of grain, feed, and husks used for food wrapping (Hock et al. 1989, 1995; Pereyda-Hernández et al. 2009; ProMED-mail 2009). When infection occurs before flowering in susceptible varieties, losses can reach 100\% (Mahuku et al. 2013).

P. maydis was first reported in Mexico in 1904 and has become endemic to Central America, South America, and the Caribbean, where it was apparently restricted for over 100 years (Cline 2020; Hock et al. 1989; Maublanc 1904; Shurtleff 1982). Tar spot was later detected and described in Bolivia, Colombia, Costa Rica, Cuba, Dominican Republic, Ecuador, El Salvador, Guatemala, Haiti, Honduras, Nicaragua, Panama, Peru, Puerto Rico, Trinidad and Tobago, U.S. Virgin Islands, and Venezuela (Abbott 1931; Arnold 1986; Bajet et al. 1994; Baker and Dale 1951; Castano 1969; Liu 1973; Malaguti and Subero 1972; McGuire and Crandall 1967; Orton 1944; Stevenson 1975; Stevenson and Cardenas 1949). In 1971, the first case of P. maydis in Brazil was documented, but since 1995, no cases of tar spot have been reported in Brazil (Hock et al. 1995; Watson 1971).

In the United States, P. maydis was first identified in 2015 in Illinois and Indiana (Ruhl et al. 2016). Since then, tar spot has been confirmed in Florida, Iowa, Michigan, Minnesota, Missouri, Ohio, Pennsylvania, and Wisconsin (Athey 2020; Collins and Esker 2020; Dalla Lana et al. 2019; Hansen et al. 2016; McCoy et al. 2018; Miller 2016). In addition, tar spot has been confirmed recently (2020) in Ontario, Canada (Tenuta 2020) (Fig. 1).

Previous research in Mexico has suggested that $P$. maydis is typically associated with two additional fungal species, Monographella maydis Müller and Samuels (endophyte or facultative parasite) and Coniothyrium phyllachorae Maubl. (hyperparasite) as part of the tar spot complex (Maublanc 1904; Müller and Samuels 1984). M. maydis has not been detected in the United States in tar spot lesions, and researchers and diagnosticians across the country have not been successful in isolating this pathogen (McCoy at al. 2019). In addition, the role of C. phyllachorae in the tar spot complex is still not clear, and no distinctive host symptom is associated with its presence (Hock et al. 1992). Hock et al. (1989) reported that the association of M. maydis with P. maydis may be responsible for the excessive leaf necrosis that occurs around tar spot lesions, giving rise to a necrotic halo (the "fisheye" symptom commonly documented for tar spot). The association between the different fungal organisms has not been demonstrated in the United States, even though the fisheye symptom is observed frequently (Kleczewski et al. 2020).

Similar to M. maydis, additional fungi have been associated with the necrotic halo. Fusarium spp. (Garcia-Aroca et al. 2018), Curvularia, Neottiosporina, and Phaeosphaeria (McCoy et al. 2019) are associated with fisheye symptoms in corn. Furthermore, McCoy et al. (2019) hypothesized that these fungi may be associated with $P$. maydis to also cause necrotic fisheye symptoms.

\section{Disease Cycle and Symptom Development}

Although tar spot has been reported for over 100 years, the exact life cycle of its causal organisms is not fully understood (Mottaleb et al. 2019). Recent studies docu- 
mented the presence of viable P. maydis ascospores on corn residue (Groves et al. 2020; Kleczewski et al. 2019b), suggesting that the sexual reproductive structures, perithecia, can overwinter and serve as a source of primary inoculum (Hock et al. 1995).

The spread of $P$. maydis ascospores occurs primarily via wind and by rain splash following forcible ejection of spores into the air (Parbery 1963). Optimal conditions for spore germination include temperatures between 16 and $20^{\circ} \mathrm{C}$, high relative humidity, and prolonged periods (at least $7 \mathrm{~h}$ ) of leaf wetness (Bajet et al. 1994; Groves et al. 2020; Hock et al. 1989; Maublanc 1904). Additional significant factors that were noted to favor the disease in Mexico include high levels of nitrogen fertilization, use of susceptible genotypes, and foggy days (Hock et al. 1989). Initially, seed infection by P. maydis or M. maydis was considered unlikely because it was thought that the fungi would not penetrate through the husk (Hock et al. 1995). However, more recent studies have demonstrated that between approximately 12 and 20 days after infection (incubation period), new stromata and ascospores are produced and the fungus can survive as stromata on corn residue like husks, leaves, and stalks (Groves et al. 2020; Kleczewski et al. 2019b).

Corn plants infected by P. maydis develop stroma that are oval to circular (sometimes angular or irregular) and small, black spots that measure 0.5 to $2.5 \mathrm{~mm}$ wide by 2 to $3 \mathrm{~mm}$ long (Fig. 2). The lesions are initially yellow to brown and quickly become brown to black, developing a narrow chlorotic border that can be seen on both sides of the leaf (Liu 1973) (Fig. 3). Dark, raised, irregularly shaped P. maydis stromata are usually observed imbedded in affected tissue but sometimes coalesce into black striations up to $10 \mathrm{~mm}$ long (Orton 1944). In fields with a prior history of this disease, these symptoms and signs are typically first observed on the lower leaves (Bajet et al. 1994) and then move up the crop canopy. Severe infections on highly susceptible hybrids can lead to stromata forming on leaf sheaths, husks, and tassels (Figs. 3 and 4).

A fisheye symptom, a circular to oval necrotic region surrounding individual stroma, has also been associated with tar spot (Fig. 5). In Mexico, Central America, South America, and the Caribbean it is thought that coinfection by M. maydis results in these fisheye symptoms that can be 10 to 30 times larger than the tar spot stroma (Bajet et al. 1994; Hock et al. 1992). As the fisheye symptoms develop, the necrotic halos often coalesce, causing extensive necrosis, ultimately leading to premature leaf senescence (Hock et al. 1992). Leaf death occurs approximately 3 to 4 weeks after

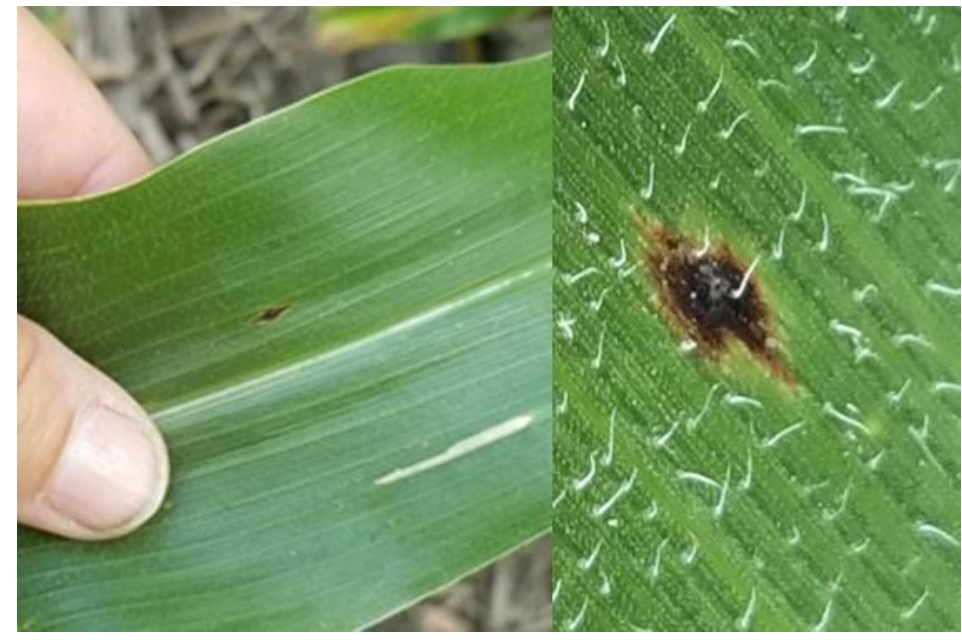

FIGURE 2

Initial tar spot presence can be identified by raised stromata of Phyllachora maydis that are oval to circular (sometimes angular or irregular) and small $(0.5$ to $2.5 \mathrm{~mm}$ wide by 2 to $3 \mathrm{~mm}$ long). The stromata are initially yellow to brown and turn brown to black, developing a narrow chlorotic border. 


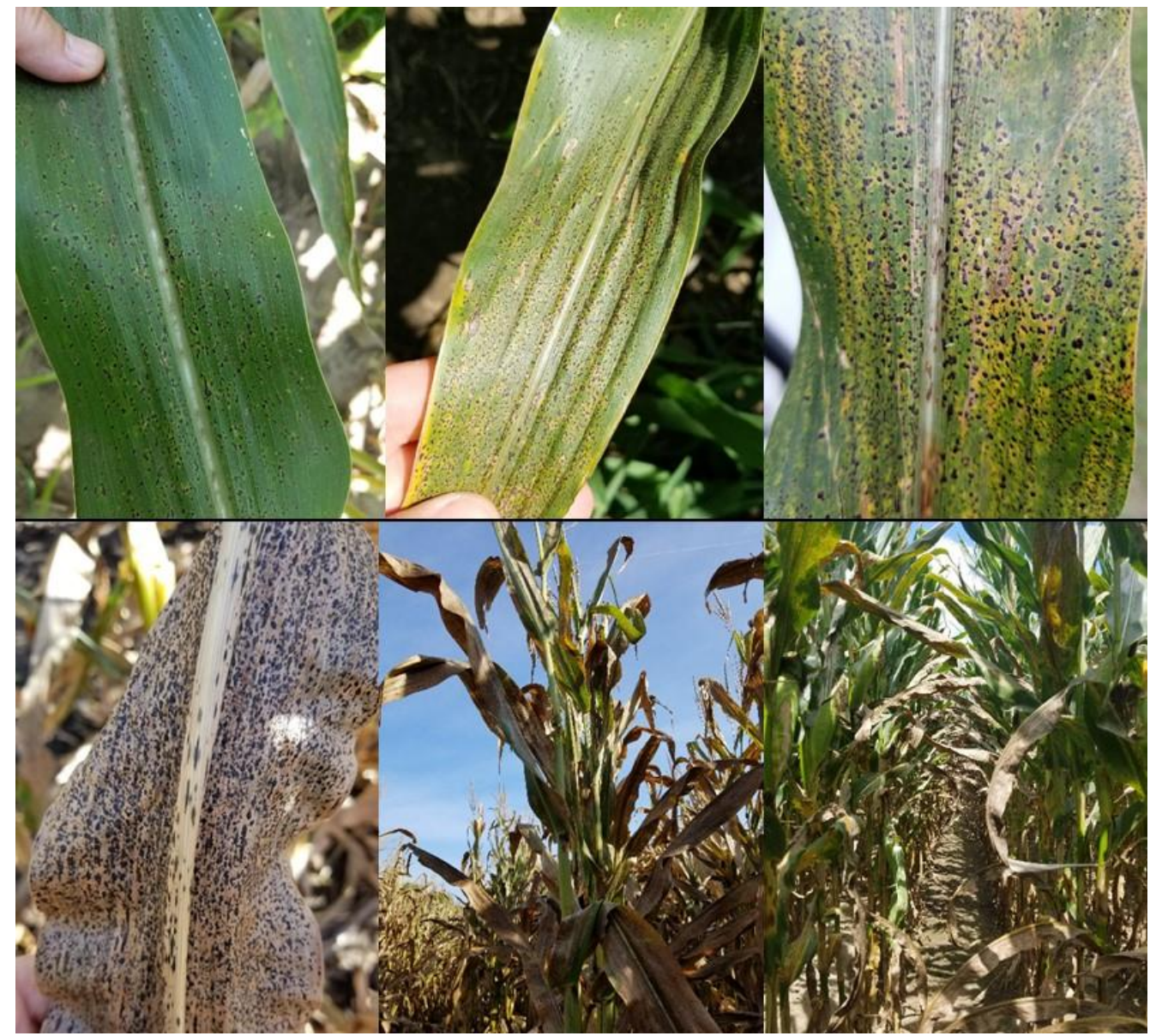

\section{FIGURE 3}

Development of Phyllachora maydis signs and tar spot symptoms in corn, as more stromata form on the leaf surface, and chlorotic and necrotic symptoms begin to develop under conditions favorable for $P$. maydis, leading to a severe blight of the leaf and crop canopy.

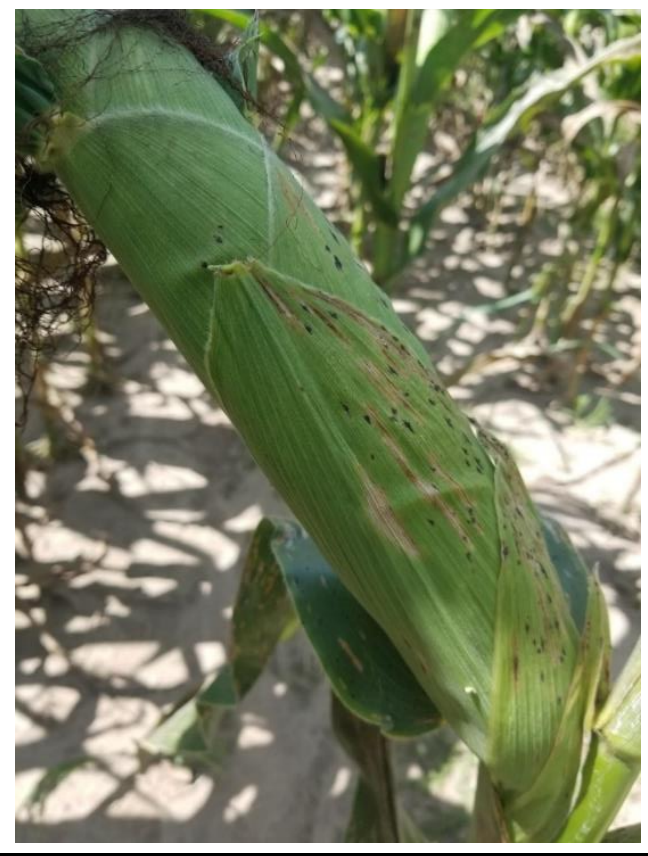

FIGURE 4

Phyllachora maydis stromata on corn husk.

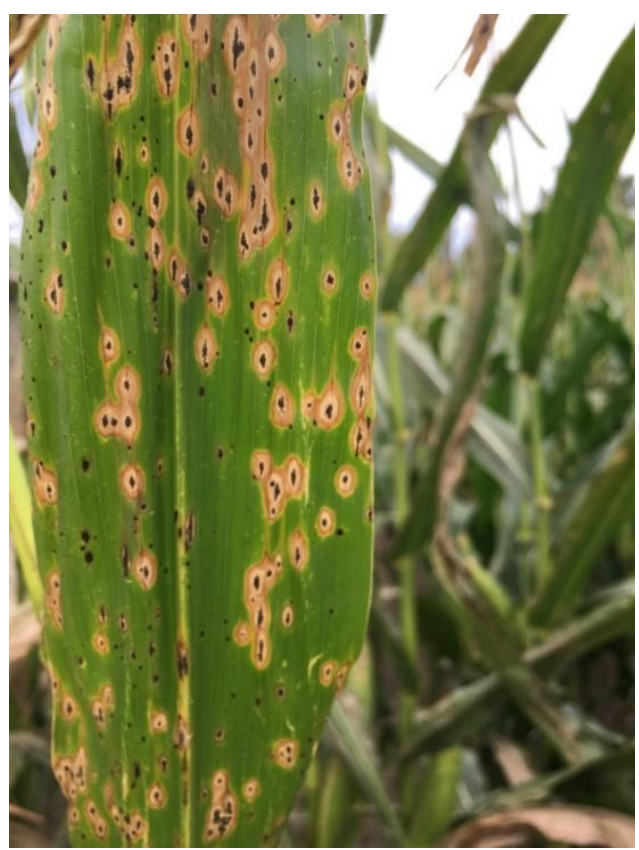

FIGURE 5

Tar spot fisheye symptoms surrounding stromata of Phyllachora maydis observed in the United States. 
infection (Hock et al. 1989). Ceballos and Deutsch (1992) suggested the accelerated senescence of corn foliage was likely due to toxins produced by M. maydis. However, in the United States, M. maydis has not been reported in leaves that exhibit fisheye symptoms (McCoy et al. 2019; Ruhl et al. 2016). Thus, toxins produced by this fungus cannot explain the observed premature leaf senescence.

\section{Spread}

The introduction of $P$. maydis to the United States is unclear. However, multiple pathways have been proposed for its introduction (Mottaleb et al. 2019). These include long-distance dispersal of inoculum through major storm events (Ruhl et al. 2016) and transport of infected husks and leaves with the wind to other locations (Richardson 1990). Furthermore, the continued documentation of new, geographically separated regions in the United States affected by $P$. maydis corroborates the idea of long-distance spread via weather events and/or movement of infected debris (Valle-Torres et al. 2020). In addition, the international trade of products containing corn husks could have contributed to the introduction of P. maydis to the United States (Mottaleb et al. 2019). Disease movement has also been shown in vegetable seeds that were contaminated through direct contact with plant debris harboring pathogens. In Fusarium wilt of aster, caused by Fusarium oxysporum f. sp. callistephi, it has been demonstrated that seeds are likely to become contaminated with spores during threshing, and the spores can also be transported on debris mixed with the seed (Kreitlow et al. 1961).

Bonde et al. (1987) reported that teliospores of Tilletia indica can be spread through the transport of contaminated and/or infected seeds, and also through air currents. In Mexico the authors were able to collect teliospores around 3,000 $\mathrm{m}$ high in the atmosphere when the wheat stubble was burned after harvest. Presumably when the wheat stubble was burned, air currents possibly carried the teliospores north into the United States (Bonde et al. 1997). Similar to the theory of how Puccinia striiformis f. sp. tritici pathogen was introduced to Australia in 1978 (Wellings 2007), Mottaleb et al. (2019) suggested that $P$. maydis could also be spread from one field to another via contamination on clothing. Hartman and Haudenshield (2009) related that urediniospores of Phakopsora pachyrhizi were observed in samples collected from shoes and trouser pants 5 days after the return of the first author from a research trip to the southern part of the United States, in which he spent 2 days in soybean fields and/or plots where the disease was present. Even though there is no documented scientific evidence to indicate that viable $P$. pachyrhizi spores have been spread by human clothing, it seems possible that this could occur.

Previous studies reported that aerial dispersal of corn residue may be important, indicating that $P$. maydis will continue to spread, posing a significant threat to corn production areas in the United States where it has not yet been documented (Kleczewski et al. 2020). Like many other species of Phyllachora, the sexual, infectious ascospores and asexual conidia (not known to cause infections) of $P$. maydis are actively discharged after extended periods of rain or high relative humidity and are often found in glutinous masses at the fungal stromata, which are then dispersed via wind and rain (Kleczewski et al. 2019a; Parbery 1963). Hock et al. (1995) found P. maydis ascospores were carried by the wind in Mexico during periods of high relative humidity (peaking at night) and found groups of three or four ascospores up to $75 \mathrm{~m}$ away from infected plants. In the presence of corn residue infested with $P$. maydis, the fungus spreads from the residue to the lower leaves and eventually reaches the upper husks of the developing ears (Bajet et al. 1994; Mahuku et al. 2016). When infection by P. maydis occurs in susceptible corn genotypes, the first symptoms are observed approximately 2 weeks after infection, with new ascospores being produced in stromata soon thereafter (Hock et al. 1995). Around $80 \%$ or more of the leaf area may be affected, reducing green plant tissue to sustain photosynthesis, or killing the plant completely in 21 to 30 days. Therefore, tar 
spot is considered one of the most devastating diseases of maize (Ceballos and Deutsch 1992; Hock et al. 1992).

\section{Monitoring and Detection}

Identification. Identification of tar spot is primarily based on the foliar symptoms and dissection of the associated fungal structures. A common sign of infection is the presence of black, glossy, raised stromata on the leaf surface and occasionally on the husk (Hock et al. 1995). The number of stromata varies with disease severity, and they can be clustered together or scattered across the leaf surface. A fisheye lesion is characterized as a halo of necrotic tissue surrounding a black stroma. Stromata with and without fisheye lesions have been observed across the United States, although the fisheye lesion occurs less frequently. The fisheye can occur at any height on the corn plant. The black, raised stromata contain the sexual structures of $P$. maydis and are 0.5 to 2 $\mathrm{mm}$ in diameter (Chalkley 2010). Dissection of mature black stromata reveals the sexual structures consisting of subglobose and ostiolate perithecia, 170 to $350 \mu \mathrm{m}$ in diameter. Perithecia can be either aggregated or scattered within a stroma. Asci that populate mature perithecia are 8 to 10 by 80 to $100 \mu \mathrm{m}$ and narrowly cylindrical. Ascospores are formed uniseriately within asci and are hyaline, aseptate, and broadly ellipsoid. Ascospore dimensions are 5.5 to 8.5 by 8 to $14 \mu \mathrm{m}$, often being 13 to $14 \mu \mathrm{m}$. Asexual conidia are also present and are hyaline, filiform, taper toward their ends, and measure 11 to 16 by 1 to $1.5 \mu \mathrm{m}$ (Chalkley 2010). Diagnostics information can be found via the USDA-ARS at https://nt.ars-grin.gov/sbmlweb/fungi/index.cfm and https:// nt.ars-grin.gov/taxadescriptions/factsheets/index.cfm?thisapp=Phyllachoramaydis.

Tar spot diagnosis does not require molecular tools, because it can be identified accurately by visual observation of its unique fungal structures. However, because infection by P. maydis has a latent period before symptom development (14 to 20 days), species-specific PCR primers have been developed for identification prior to symptom onset (E. Roggenkamp, personal communication; Valle-Torres et al. 2020). Molecular tools also could be useful to continue to test for the possible presence of M. maydis in fisheye symptoms, in case that organism eventually appears in the United States. Due to its obligate biotrophic nature, P. maydis has not been cultured on media in the laboratory, and diagnostic samples must be identified directly from infected plant material.

Monitoring. Due to its distinct symptoms, growers, Extension, and industry personnel can often confirm tar spot in the field without sending samples to a diagnostic laboratory. Rapid confirmation of tar spot cases is important in monitoring the spread of $P$. maydis throughout corn-growing regions. Tar spot confirmations are reported and tracked by university plant pathology Extension personnel throughout the growing season via the ipmPIPE (ipmPIPE 2020). Each year, additional confirmations are recorded to document the spread of $P$. maydis to previously unreported U.S. states/counties or Canadian provinces. The current monitoring system allows for rapid responses and information sharing among stakeholders, which can inform scouting and management decisions. Advanced syndromic systems are currently being developed to more rapidly aid detection and quantification of tar spot signs and symptoms in the field (C. Cruz et al., personal communication).

\section{Response}

Since the initial confirmation of corn tar spot in the United States in 2015 and a major epidemic in 2018, Extension field crop pathologists in collaboration with state diagnostic labs have made a concerted effort to continue to document the annual distribution and spread of tar spot. Tar spot is now considered established in many regions and future efforts should focus on management practices that will limit its impact on corn production. 
The response to all plant health emergencies is under USDA-APHIS-Plant Protection under The Plant Protection Act of 2000 (7 CFR Part 330) and the Agricultural Bioterrorism Protection Act of 2002 (7CFR Part 331).

\section{Permits and Regulatory Issues}

The applicable regulations effective August 9, 2019, can be found at https:// www.federalregister.gov/documents/2019/06/25/2019-13246/plant-pest-regulations.

USDA/APHIS/PPQ permit and registration requirements for plant diseases and laboratories fall under two authorities: the Plant Protection Act (7 CFR Part 330) and the Agricultural Bioterrorism Protection Act (7 CFR Part 331). The Plant Protection Act permit applies to all plant pests and infected plant materials, including diagnostic samples, regardless of their quarantine status, that are shipped interstate and require that the receiving laboratory have a permit. For additional guidance on permitting of plant pest material, consult the PPQ Permit website at http://www.aphis.usda.gov/ ppq/permits/ or contact PPQ Permit services at 301-851-2357.

P. maydis is not an exotic plant pathogen in the United States. Therefore, it does not need to be housed and experimented on within Biosafety Level 3 containment facilities approved by the USDA APHIS.

\section{Economic Impacts}

The United States is the global leader in corn production with 13.6 billion bushels (345 million metric tons [MMT]) produced in 2019, valued at US\$52.9 billion (USDANASS 2019). Since the first detection of P. maydis in the United States in 2015, its significant effects on yield have been demonstrated, and the potential economic impacts due to its spread across the corn belt are of serious concern (Kleczewski and Bowman 2021). Yield losses due to tar spot in the United States were first recorded in 2018 and have been highly variable between years since its introduction (Mueller et al. 2020, 2021). From 2018 to 2020, estimated yield losses due to tar spot across the Midwestern United States totaled 241 million bushels (6.1 MMT).

In Mexico, the tar spot disease complex has been an economically important disease of corn for decades, and when infection occurs before flowering in susceptible varieties, grain, and fodder, losses can reach 100\% (Mahuku et al. 2013). Individual fields in the United States have experienced yield losses up to 50 bushels per acre (approximately a $25 \%$ loss), and economic impacts on growers are likely to be compounded by the need for fungicide applications for tar spot management when conditions are highly favorable on susceptible hybrids (Chilvers et al. 2018; Jeschke 2019; Telenko et al. 2020). Until fungicide application timing is better understood, tar spot management in years when weather is highly conducive for tar spot development may require two fungicide applications to avoid significant yield losses. Two foliar fungicide applications are typically not economical for individual growers (Hershman et al. 2011; Schindo 2019). Development of resistant hybrids and additional management strategies are important to ease economic impacts on growers due to tar spot.

Economic losses due to tar spot are largely dependent on hybrid resistance level and the favorability of the environment for fungal dissemination, infection, and disease development (Hock et al. 1995; Telenko et al. 2019). With the development of tar spotresistant germplasm suitable for U.S. and Canadian corn-growing regions still underway, the potential for losses increases with the spread of $P$. maydis across the United States and Canada. A climate analogue analysis was conducted to identify the potential range of $P$. maydis within the United States based on the climate similarity to its range in Mexico, Central America, South America, and the Caribbean and to estimate the potential economic losses due to tar spot spread (Mottaleb et al. 2019). It was estimated that a tar spot outbreak resulting in 1 to $5 \%$ yield decrease is estimated to result in a 2.8 
to 14.1 MMT loss, which would equate to economic losses of US\$446 million to US\$2.2 billion (Mottaleb et al. 2019). Recently, the disease has been observed in the nontropical maize-growing regions with temperate or colder climates, such as the high elevation plateaus of Central Mexico at over 2,600 m above sea level (Ríos-Herrera et al. 2016). Without adequate hybrid resistance and additional mitigation strategies, the potential economic losses due to tar spot in the United States could be significant (Mottaleb et al. 2019).

\section{Mitigation and Disease Management}

P. maydis is now established in the United States and has spread to multiple states within the U.S. corn belt as well as Ontario, Canada, making eradication improbable (ipmPIPE 2020). Tar spot management will likely rely on an integrated approach using genetic resistance, chemical application, and cultural control. Some management strategies not discussed may be effective but have yet to be investigated. Disease management options are described in the following section.

Hybrid selection and host resistance. The use of resistant germplasm is an effective, economical, and environmentally friendly disease management strategy in many crops. Corn hybrids used in the native range of $P$. maydis vary in their susceptibility to tar spot, but all incur some level of disease severity under high inoculum pressure and favorable environmental conditions (Pereyda-Hernández et al. 2009). Since the first detection of tar spot in the United States, commercial hybrid screenings have been included at university and commercial hybrid performance trials to evaluate their susceptibility to infection (Telenko et al. 2019). Performance trials have been important in generating data to be used by growers and advisors in selection of hybrids for tar spot management. Existing commercial corn hybrids range in their susceptibility to $P$. maydis infection and offer growers only partial resistance (Singh et al. 2018). In the 2018 university hybrid performance trials across the Midwest, a relationship between hybrid maturity and tar spot severity was observed, with later-maturing corn hybrids incurring higher disease severity ratings and greater yield losses than those with earlier maturity (Telenko et al. 2019). Tar spot is a disease that typically develops later in the growing season in the United States; thus, later-maturity corn hybrids have longer susceptible periods compared with those that mature earlier. This leads to a greater risk of damage by tar spot for later-maturing hybrids. Further development of commercial hybrids with improved resistance to $P$. maydis infection and tar spot is needed to protect growers from yield losses. The associated work will rely on identifying genetic sources of resistance and incorporating them into hybrids suitable for commercial use. Several inbred lines in the maize nested association mapping (NAM) population with variable resistance have been identified (R. Singh, personal communication). Ongoing work on breeding efforts could provide information on genetic locus and candidate genes associated with tar spot resistance.

Efforts to screen diverse panels of corn germplasm suited for tropical and subtropical regions identified a single major quantitative trait locus (QTL), qRtsc8-1, that is consistently present in tropical and subtropical corn varieties and is associated with tar spot resistance (Cao et al. 2017; Ceballos and Deutsch 1992; Mahuku et al. 2016). Candidate gene analysis showed that $q R t s c 8-1$ may be a leucine-rich repeat receptorlike protein gene, which is typical of a major resistance gene (Mahuku et al. 2016). Multiple haplotypes within this QTL region were associated with increased tar spot resistance, but a single rare haplotype, occurring at a frequency of $3.5 \%$, increased resistance to tar spot by $14 \%$ (Mahuku et al. 2016). Between 18 and $43 \%$ of the observed disease severity variation in response to tar spot infection is accounted for by qRtsc8-1 when present (Mahuku et al. 2016). Tar spot resistance associated with this QTL was also reported to be highly heritable (Ceballos and Deutsch 1992). The discovery of $q$ Rtsc 8 - 1 , the high heritability of tar spot resistance, and the use of marker- 
assisted selection for breeding may aid in the development of hybrids with enhanced resistance. However, there are risks associated with using a single source of genetic resistance with the potential for new pathogen biotypes emerging to overcome resistance. Consequently, research to identify additional potential sources of genetic resistance is still needed (Ceballos and Deutsch 1992). Moreover, the maize genomic regions associated with tar spot resistance could also be targeted for germplasm improvement through a genome editing approach.

Chemical control. In Mexico, research has been conducted to find effective fungicide regimens against tar spot, but updated studies are necessary to test commercially available fungicides and potential new compounds as well as different application timing strategies for growers managing tar spot in the United States and Canada (Bajet et al. 1994; Pereyda-Hernández et al. 2009). Therefore, fungicide trials have been established to develop data and recommendations for growers to protect their crops against losses. Foliar fungicide applications have reduced disease and yield losses compared with no treatment, and popular mixed-modes-of-action fungicide products demonstrated good efficacy against tar spot (Corn Disease Working Group 2020). However, fungicide applications that reduce disease severity do not always result in significant yield differences, which may be due in part to field variability (Chilvers et al. 2018). Efficacy did not differ widely among the mixed-mode-of-action fungicides tested, with many offering good or very good efficacy (Table 1). Instead, timing of fungicide application relative to corn growth stage and onset of tar spot may be the most important factor in determining the benefits and success of a fungicide application and avoiding the need for multiple applications (Jeschke 2019; Telenko et al. 2020).

\begin{tabular}{|c|c|c|c|}
\hline \multicolumn{4}{|c|}{$\begin{array}{c}\text { TABLE } 1 \\
\text { Fungicides currently labeled for tar spot as of February } 2021 \text { in corn in the United States }\end{array}$} \\
\hline Product name & Active ingredient (\%) & FRAC code ${ }^{b}$ & Rate/acre \\
\hline Aproach $2.08 \mathrm{SC}^{\mathrm{c}}$ & Picoxystrobin $(22.5 \%)$ & 11 & $3.0-12.0 \mathrm{fl} \mathrm{oz}$ \\
\hline Domark $230 \mathrm{ME}$ & Tetraconazole $(20.5 \%)$ & 3 & $4.0-6.0 \mathrm{fl} \mathrm{oz}$ \\
\hline Affiance $1.5 \mathrm{SC}^{\mathrm{c}}$ & Tetraconazole $(7.48 \%)+$ azoxystrobin $(9.35 \%)$ & $3+11$ & $10.0-14.0 \mathrm{fl} \mathrm{oz}$ \\
\hline $\begin{array}{l}\text { Aproach Prima } 2.34 \\
\text { SC }^{c}\end{array}$ & Cyproconazole $(7.17 \%)+$ picoxystrobin $(17.94 \%)$ & $3+11$ & $3.4-6.8 \mathrm{fl} \mathrm{oz}$ \\
\hline $\begin{array}{l}\text { Fortix } 3.22 \mathrm{SC}^{\mathrm{c}} / \\
\quad \text { Preemptor } 3.22 \mathrm{SC}^{\mathrm{c}}\end{array}$ & Flutriafol $(19.3 \%)+$ fluoxastrobin $(14.84 \%)$ & $3+11$ & $4.0-6.0 \mathrm{fl} \mathrm{oz}$ \\
\hline Headline AMP $1.68 \mathrm{SC}$ & Pyraclostrobin $(13.6 \%)+$ metconazole $(5.1 \%)$ & $11+3$ & $10.0-14.4 \mathrm{fl} \mathrm{oz}$ \\
\hline Lucento & Flutriafol $(26.47 \%)+$ bixafen $(15.55 \%)$ & $3+7$ & $3.0-5.5 \mathrm{fl} \mathrm{oz}$ \\
\hline Priaxor $4.17 \mathrm{SC}^{\mathrm{c}}$ & Pyraclostrobin $(28.58 \%)+$ fluxapyroxad $(14.33 \%)$ & $11+3$ & $4.0-8.0 \mathrm{fl} \mathrm{oz}$ \\
\hline $\begin{array}{l}\text { Quilt Xcel 2.2 } \mathrm{SE}^{\mathrm{c}} \\
\text { (multiple generics) }\end{array}$ & Azoxystrobin $(13.5 \%)+$ propiconazole $(11.7 \%)$ & $11+3$ & $10.5-14.0 \mathrm{fl} \mathrm{oz}$ \\
\hline TopGuard EQ ${ }^{c}$ & Flutriafol $(18.63 \%)+$ azoxystrobin $(25.30 \%)$ & $3+11$ & $5.0-7.0 \mathrm{fl} \mathrm{oz}$ \\
\hline Veltyma & Mefentrifluconazole $(11.61 \%)+$ pyraclostrobin $(17.56 \%)$ & $3+11$ & $7 \mathrm{fl} \mathrm{oz}$ \\
\hline Delaro 325 SC & Prothioconazole $(16.0 \%)+$ trifloxystrobin $(13.7 \%)$ & $3+11$ & $8.0-12.0 \mathrm{fl} \mathrm{oz}$ \\
\hline $\begin{array}{l}\text { Delaro Complete } 3.83 \\
\quad \text { SC }\end{array}$ & $\begin{array}{l}\text { Prothioconazole }(14.9 \%)+\text { trifloxystrobin }(13.1 \%)+ \\
\quad \text { fluopyram }(10.9 \%)\end{array}$ & $3+11+7$ & $8.0-12.0 \mathrm{fl} \mathrm{oz}$ \\
\hline Miravis Neo $2.5 \mathrm{SE}$ & $\begin{array}{l}\text { Pydiflumetofen }(7.0 \%)+\text { azoxystrobin }(9.3 \%)+ \\
\text { propiconazole }(11.6 \%)\end{array}$ & $7+11+3$ & $13.7 \mathrm{fl} \mathrm{oz}$ \\
\hline Revytek & $\begin{array}{l}\text { Mefentrifluconazole }(11.61 \%)+\text { pyraclostrobin }(15.49 \%)+ \\
\text { fluxapyroxad }(7.74 \%)\end{array}$ & $3+11+7$ & $8.0-15.0 \mathrm{fl} \mathrm{oz}$ \\
\hline Trivapro $2.21 \mathrm{SE}$ & $\begin{array}{l}\text { Benzovindiflupyr }(2.9 \%)+\text { azoxystrobin }(10.5 \%)+ \\
\text { propiconazole }(11.9 \%)\end{array}$ & $7+11+3$ & $13.7 \mathrm{fl} \mathrm{oz}$ \\
\hline
\end{tabular}

a For current information on efficacy of products see Crop Protection Network publication - Fungicide efficacy for control of corn diseases at https://doi.org/10.31274/cpn-20210318-0. Reference in this table to any specific commercial product or the use of any trade, firm, or corporation name is for general informational purposes only and does not constitute an endorsement, recommendation, or certification of any kind. It is the applicator's legal responsibility to read and follow all current label directions. Information included is by no means a complete list of all products available. Individuals using such products assume responsibility for their use in accordance with current directions of the manufacturer.

b FRAC codes are designated by the Fungicide Resistance Action Committee as a system to identify active ingredient mode of action and resistance risk (FRAC 2021; http://www.frac.info/).

c A 2ee label is available for several fungicides for control of tar spot. However, efficacy data are limited. Check 2ee labels carefully, as not all products have 2ee labels in all states. 
Due to the potentially explosive nature of tar spot, optimal timing of a fungicide application is key to reducing inoculum of $P$. maydis for subsequent infection cycles throughout the growing season. Fungicide timing trials have been conducted, but variability in disease onset and environmental conditions between years has made it difficult to discern the optimal timing for applications (Telenko et al. 2020). Applications during corn reproductive stages have been most effective for controlling tar spot, whereas those during vegetative stages appear to be too early to control late-season tar spot epidemics that are more typical in most growing seasons in the United States and Canada. In a 2020 fungicide timing trial, a single spray at silking (growth stage R1) saved 24 to 48 bushels per acre of yield compared with a nontreated control (Singh et al. 2020). Severe tar spot infestations can also reduce stalk integrity, and well-timed fungicide applications can help reduce lodging and avoid associated harvesting issues (Telenko et al. 2020). Using an action threshold based on disease severity or incidence to determine optimal fungicide application timing is another common integrated pest management strategy (Carisse and McNealis 2019; Carisse et al. 2009). Development of quantitative spray thresholds is an additional part of the field research underway to optimize fungicide applications (M. Chilvers, personal communication). Many of the most efficacious tar spot fungicides are also effective against other economically important corn foliar diseases, and university Extension specialists also work collaboratively to provide data for a fungicide efficacy table for tar spot as well as additional corn foliar diseases, which can be found at https://cropprotectionnetwork.org/ (https://doi.org/10.31274/cpn-20210318-0).

An additional tool in development for growers is a tar spot disease risk assessment smartphone application (app) called Tarspotter (Smith 2019). Tarspotter uses internetaccessible weather data that is GPS referenced to feed statistical models for tar spot prediction. Using weather data and models, Tarspotter generates probability-based prediction of risk of tar spot to aid growers in fungicide application decision making. A risk-prediction value above a defined action threshold set by developers lets growers know whether they should consider a fungicide application to avoid damage due to tar spot (Smith 2020). Tarspotter is still in development and is being validated against field observations across the Midwest through collaborations among university Extension and industry personnel (Smith 2019).

Biological control. Although there are not currently biological control management strategies available for tar spot of corn, various biological control agents have been proposed (Hock et al. 1995; McCoy et al. 2019). In Mexico, Central America, South America, and the Caribbean, where tar spot is considered a disease complex, Coniothyrium phyllachorae is implicated as a member and a hyperparasite of $P$. maydis (Hock et al. 1992). Hock et al. (1995) reported a high incidence of hyperparasitism at the end of the growing season, with $50 \%$ of $P$. maydis ascomata infected with C. phyllachorae 2 weeks before corn harvest. They also noted that the hyperparasitized lesions were often smaller with less necrosis. A fungal community network analysis conducted by McCoy et al. (2019) reported negative associations between P. maydis and phylloplane yeasts belonging to the genera Bullera and Dioszegia, suggesting these genera may contain species that are antagonistic to $P$. maydis on the corn leaf surface. This observation was made in both tissues with tar spot signs alone and in tissues with stromata and fisheye symptoms. To investigate the potential of these fungi as biological control agents, experiments on their interactions need to be conducted to identify any antifungal activity against $P$. maydis.

Cultural management. Tillage and crop rotation appear to offer little potential to reduce tar spot severity, with instances of previously noninfested corn fields becoming heavily infested (M. Chilvers, D. Malvick, and D. Telenko, personal communication). Tillage and crop rotation may reduce the initial inoculum level or inoculum buildup, but the ability of $P$. maydis spores to blow in from neighboring fields renders these 
management strategies ineffective in tar spot control (Kleczewski and Bowman 2021; Kleczewski et al. 2019a).

Water management may be an important factor in reducing tar spot pressure in irrigated fields. Irrigation creates an environment in the corn canopy with increased humidity, decreased temperature, and the presence of free water on leaves (Cavero et al. 2009; Turkington et al. 2004). Irrigated crops also can develop denser canopies, which affect the canopy microclimate in similar ways, creating a more favorable environment for P. maydis spore dissemination and infection (Hock et al. 1995; Rotem and Palti 1969). The epidemiology of $P$. maydis highlights its affinity for cool temperatures, high humidity, and leaf wetness (Hock et al. 1995). Anecdotal evidence has noted an increase in tar spot severity under irrigation compared with nonirrigated sections of a field (Chilvers and Telenko 2020; Telenko et al. 2020). However, irrigation is still needed in many cases to maximize yield potential, even if there is added risk of increasing disease. Future research efforts will focus on irrigation best management practices to reduce yield losses due to tar spot, such as irrigating during the day and avoiding frequent irrigation events (Chilvers and Telenko 2020).

Limiting transportation of infested corn materials may slow the spread of $P$. maydis and distribution of inoculum across the United States and Canada. The original source of inoculum in the United States is unknown, but hypotheses regarding the introduction of $P$. maydis into the United States include the movement of infested corn material, people, and atmospheric transport (Valle-Torres et al. 2020). P. maydis is not a seedborne pathogen, and spread via infected seed is not a concern (Hock et al. 1995, Richardson 1990). However, movement of corn stover and grains contaminated with infested leaf or husk material may pose a risk in spreading the pathogen to previously noninfected areas. Geographically separated cases of tar spot emergence may demonstrate the need for restrictions on the movement of corn materials infested with P. maydis to limit additional spread across the United States and Canada (ipmPIPE 2020).

Fertility can be an important factor in controlling some diseases, as nutrition can affect the interactions between plant, pathogen, and environment (Huber and Haneklaus 2007). The relationship between nitrogen and tar spot severity has been explored, but altering nitrogen nutrition rates has not affected tar spot severity (J. Check, personal communication). Other macro- and micronutrients should also be explored for potential disease control strategies.

Dense plant canopies have been associated with greater disease severity in some pathosystems, and decreasing planting populations could be one way to reduce canopy density (Vieira et al. 2010). However, field trials investigating the relationship between planting population and tar spot severity have shown that increased tar spot severity is associated with lower but not higher planting populations (J. Check, personal communication). A proposed hypothesis to explain this effect is that corn canopies in lower planting populations lose energy via radiative heat loss more rapidly than those in higher planting populations, which could potentially create a more favorable environment for fungal growth and dissemination (M. Chilvers, personal communication). Lower planting populations may also have increased air flow and allow P. maydis spores to disperse more easily throughout the plant canopy. Regardless of the reason, moderate to high planting populations may result in reduced tar spot severity in commercial fields, although additional work is needed to explain what may be driving this effect.

Integrated management. Approaches to tar spot management will need to be multifaceted. Future research to identify optimal and new strategies is underway and will continue to aid in the development of recommendations for growers to reduce or avoid losses due to tar spot. Strategies to manage tar spot include the following:

- Monitoring fields and scouting for tar spot to properly time fungicide applications and reduce $P$. maydis inoculum early in the growing season. 
- Using partially resistant hybrids and avoiding those that are highly susceptible to tar spot.

- Chemical control using efficacious mixed-mode-of-action fungicides and applications at optimal corn growth stages for best control.

- Using risk-prediction models and spray thresholds to optimally plan fungicide applications.

- Properly irrigating to reduce leaf wetness duration and reduce $P$. maydis infection, slow reproduction, and reduce inoculum buildup.

- Harvesting early if severe lodging issues are expected due to tar spot.

\section{Infrastructure and Experts}

National Plant Diagnostic Network - https://www.npdn.org/home

Domestic scientific university experts on tar spot of corn (authors acknowledge that this list is not exhaustive and does not include industry experts):

\section{University plant pathologists}

Bissonnette, Kaitlyn - University of Missouri, BissonnetteK@missouri.edu, 573-882-9106

Byamukama, Emmanuel - South Dakota State University, emmanuel.byamukama@sdstate.edu, 605-688-4521

Chilvers, Martin - Michigan State University, chilvers@msu.edu, 517-353-9967

Collins, Alyssa - Pennsylvania State University, aac18@psu.edu, 717-653-4728

Cruz, Christian - Purdue University, cd-cruz@purdue.edu, 765-494-1515

Esker, Paul - Pennsylvania State University, pde6@psu.edu, 814-865-0680

Friskop, Andrew - North Dakota State University,

Andrew.j.friskop@ndsu.edu, 701-231-7627

Goodwin, Stephen - USDA-ARS, Purdue University, sgoodwin@purdue.edu, 765-494-4635

Jackson-Ziems, Tamra - University of Nebraska-Lincoln, tjackson3@unl.edu, 402-472-2559

Malvick, Dean - University of Minnesota, dmalvick@umn.edu, 612-625-5282

Mueller, Daren - Iowa State University, dsmuelle@iastate.edu, 515-460-8000

Onofre, Rodrigo - Kansas State University, onofre@ksu.edu

Paul, Pierce - The Ohio State University, paul.661 @ osu.edu, 330-263-3842

Robertson, Alison - Iowa State University, alisonr@iastate.edu, 515-294-6708

Smith, Damon - University of Wisconsin, damon.smith@wisc.edu, 608-286-9706

Telenko, Darcy - Purdue University, dtelenko@ purdue.edu, 765-496-5168

Tenuta, Albert - Ontario Ministry of Agriculture, Food and Rural Affairs, albert.tenuta@ontario.ca, 519-360-8307

Wise, Kiersten - University of Kentucky, kiersten.wise@uky.edu, 859-562-1338 
University corn geneticists

Jamann, Tiffany - University of Illinois

Thompson, Addie - Michigan State University

\section{International scientific experts on tar spot of corn include:}

Alakonya, Amos Emitati - Plant Pathologist and Head of Seed Health Unit, International Maize and Wheat Improvement Center (CIMMYT), +525951225959 (cell), A.Alakonya@ cgiar.org

Dhliwayo, Thanda - CIMMYT maize breeder, D.Thanda@cgiar.org

San Vincente García, Félix Manuel - CIMMYT maize breeder, F.SanVicente@cgiar.org

\section{Research, Extension, and Education Priorities}

\section{RESEARCH PRIORITIES}

The following research is needed to continue to improve effective tar spot monitoring and management in corn. These are research areas necessary to increase knowledge about biological, environmental, and economic aspects of the disease as it impacts the U.S. and Canadian corn sectors.

Continue to monitor the movement, establishment, and survival of $\boldsymbol{P}$. maydis in the United States and Canada.

- Continue the use of EDDMap/corn ipmPIPE and collaboration with state diagnostic laboratories to monitor for $P$. maydis spread into new areas in North America.

- Develop and improve reliable pathogen detection capabilities (spore traps, soil samples, etc.).

- Expand our understanding of overwintering and survival of the pathogen in the absence of the host.

- Continue to investigate the possible involvement of other pathogens in U.S. tar spot outbreaks.

- Continue with the development of accurate and precise syndromic methods to monitor the movement of signs and symptoms at the field and regional levels.

- Better understand the spatiotemporal development of signs and symptoms at various geographical levels.

Evaluate resistance of corn germplasm to tar spot for the U.S. and Canadian markets in conjunction with seed corn companies.

- Characterize susceptibility of breeding lines, hybrids, sweet corn, popcorn, and open-pollinated varieties to tar spot.

- Develop resistance screening programs for corn.

- Identify novel tar spot resistance QTLs or candidate resistance genes.

\section{Develop best disease management practices for tar spot in corn.}

- Continue evaluations of both chemical fungicides and biological control agents for efficacy.

- Encourage the development of new fungicides for disease management.

- Determine optimum fungicide application timings based on disease detection, rates of disease development and spread, and weather models.

- Expand our understanding of integrated disease management programs that include fungicides, partially resistant hybrids, crop rotation, plant population modification, tillage, and additional cultural practices to reduce or mitigate tar spot development. 
- Improve understanding of the impact of irrigation on disease development to limit risk while providing adequate moisture to the crop.

Expand epidemiological and ecological knowledge about tar spot.

- Expand our limited understanding of the disease cycle.

- Monitor spatial and temporal movement within the canopy as well as long-range movement of $P$. maydis spores in U.S. corn production areas.

- Continue to develop and validate tar spot prediction tools based on weather and research models (e.g., Tarspotter).

- Explore disease dynamics, infection process, survival in debris, and confirm limited host range and relationship to other species of Phyllachora.

\section{EXTENSION AND EDUCATION NEEDS}

Information about tar spot identification and management is available from various online sources (see Web Resources). Knowledge of new observations in undocumented counties should be reported to state/provincial plant disease diagnostic laboratories and shared with the corn ipmPIPE (see Infrastructure and Experts), so that newly infested counties can be included on a distribution map. Continue to expand and develop training materials on disease identification and management and other resources for use by county Extension educators, industry personnel, and growers.

Educational efforts should continue to inform the corn industry and public about the potential risks and best disease management practices.

\section{Timeline for Recovery}

Given the recent (2015) emergence and rapid spread of tar spot within the United States (Bissonnette 2015; Dalla Lana et al. 2019; McCoy et al. 2018; Malvick et al. 2020; Ruhl et al. 2016), reliable short- and long-term recovery measures remain limited. Despite this, several factors are now known to influence tar spot recovery times, including (i) geographic location, (ii) disease severity, (iii) cultivar, and (iv) weather (reviewed in Valle-Torres et al. 2020). Disease severity year-to-year is more highly influenced by weather conditions than by previous-year disease severity. Tar spot development is optimal during periods of cool temperatures from 17 to $22^{\circ} \mathrm{C}$ and extended periods of high relative humidity ( $>75 \%$ ) (Hock et al. 1995). The pathogen can overwinter on corn residue in the northern United States (Groves et al. 2020; Kleczewski et al. 2019b), a process that remains poorly understood for $P$. maydis. Furthermore, at the present time, no known corn hybrids exist that are completely resistant to tar spot (Telenko et al. 2019). Alternatively, several fungicides demonstrate moderate to high efficacy against $P$. maydis (Corn Disease Working Group 2020). Among fungicides tested, appropriate application timing is critical for controlling tar spot and is recommended immediately following the onset of symptoms. Fungicides can carry widely variable preharvest restrictions, so careful consideration of these should be made before application. Collectively, additional fundamental research into the life cycle, molecular mechanisms of host identification and subsequent infection, potential for fungicide resistance, and dispersal patterns of $P$. maydis are needed to identify new ways to ultimately mitigate tar spot. Likewise, additional identification of hybrid corn lines with reduced P. maydis susceptibility is needed for short- and longterm relief.

\section{References}

Abbott, E. 1931. Further notes on plant diseases in Peru. Phytopathology 21:1061-1071. Arnold, G. R. W. 1986. Lista de hongos fitopatogenicos de Cuba. Editorial CientificoTecnica, Havana, Cuba.

Athey, S. 2020. Emerging diseases in Missouri corn, soybeans. Farm Talk Newspaper, Parsons, KS. https://www.farmtalknews.com/news/emerging-diseases-in-missouri-corn- 
soybeans/article_fe96d578-41e4-11ea-a20a-9bbea678228e.html. Accessed December $17,2020$.

Bajet, N. B., Renfro, B. L., and Valdez Carrasco, J. M. 1994. Control of tar spot of maize and its effect on yield. Int. J. Pest Manag. 40:121-125. doi: 10.1080/ 09670879409371868.

Baker, R., and Dale, W. T. 1951. Fungi of Trinidad and Tobago. Mycological Papers 33, Commonwealth Mycological Institute, Kew, U.K.

Bissonnette, S. 2015. Corn disease alert: New fungal leaf disease "tar spot" Phyllachora maydis identified in 3 northern Illinois counties. The Bulletin: Pest Management and Crop Development Information for Illinois.

Bonde, M. R., Prescott, J. M., Matsumoto, T. T., and Peterson, G. L. 1987. Possible dissemination of teliospores of Tilletia indica by the practice of burning wheat stubble. (Abstr.) Phytopathology 77:639.

Bonde, M. R., Peterson, G. L., Schaad, N. W., and Smilanick, J. L. 1997. Karnal bunt of wheat. Plant Dis. 81:1370-1377. doi: 10.1094/PDIS.1997.81.12.1370.

Cao, S., Loladze, A., Yuan, Y., Wu, Y., Zhang, A., Chen, J., Huestis, G., Cao, J., Chaikam, V., Olsen, M., Prasanna, B., San Vicente, F., and Zhang, X. 2017. Genome-wide analysis of tar spot complex resistance in maize using genotype-by-sequencing SNPs and whole genome prediction. Plant Genome 10:1-14.

Carisse, O., and McNealis, V. 2019. Development of action threshold to manage common leaf spot and black seed disease of strawberry caused by Mycosphaerella fragariae. Plant Dis. 103:563-570.

Carisse, O., Meloche, C., Boivin, G., and Jobin, T. 2009. Action thresholds for summer fungicide sprays and sequential classification of apple scab incidence. Plant Dis. 93:490498.

Castano, M. L. 1969. Mancha de asfalto (tar spot) de la hoja del maiz. Agric. Trop. 25:332.

Cavero, J., Medina, E. T., Puig, M., and Martínez-Cob, A. 2009. Sprinkler irrigation changes maize canopy microclimate and crop water status, transpiration, and temperature. J. Agron. 101:854-864.

Ceballos, H., and Deutsch, J. A. 1992. Inheritance of resistance to tar spot complex in maize. Phytopathology 82:505-512.

Chalkley, D. 2010. Tar spot of corn - Phyllachora maydis. Systematic Mycology and Microbiology Laboratory, ARS, USDA. Invasive Fungi Fact Sheets. https://nt.arsgrin.gov/taxadescriptions/factsheets/index.cfm?thisapp=Phyllachoramaydis\&printtype $=$. Accessed March 13, 2021.

Chilvers, M. I., and Telenko, D. E. P. 2020. Irrigation management to reduce cost and foliar disease. MSU Extension, June 1, 2020. https://www.canr.msu.edu/news/irrigationmanagement-to-reduce-cost-and-foliar-disease.

Chilvers, M., McCoy, A., Byrne, A., Cornett, A., Chang, H., Noel, Z., and Koeman, S. 2018. Effects of fungicides on the management of tar spot of corn in Michigan. Plant Dis. Manage. Rep. 13:CF016.

Cline, E. 2020. Phyllachora maydis. U.S. National Fungus Collections, ARS, USDA. https://nt.ars-grin.gov/sbmlweb/fungi/NomenSheets.cfm. Accessed November 8, 2020.

Collins, A., and Esker, P. D. 2020. Tar spot: A new corn disease for Pennsylvania. https://extension.psu.edu/tar-spot-a-new-corn-disease-for-pennsylvania. Accessed December 17, 2020.

Corn Disease Working Group. 2020. Fungicide efficacy for control of corn diseases. Corn Disease Management. CPN-2011. doi: 10.31274/cpn-20190620-002.

Dalla Lana, F., Plewa, D. E., Phillippi, E. S., Garzonio, D., Hesterman, R., Kleczewski, N. M., and Paul, P. A. 2019. First report of tar spot of maize (Zea mays), caused by Phyllachora maydis, in Ohio. Plant Dis. 103:1780.

Fungicide Resistance Action Committee (FRAC). 2021. FRAC Code List ${ }^{\mathfrak{O}} 2021$. https://www.frac.info/.

Garcia-Aroca, T., Doyle, V., Singh, R., Price, T., and Collins, K. 2018. First report of Curvularia leaf spot of corn, caused by Curvularia lunata, in the United States. Plant Health Prog. 19:140-142. doi: 10.1094/PHP-02-18-0008-BR.

Groves, C. L., Kleczewski, N. M., Telenko, D. E. P., Chilvers, M. I., and Smith, D. L. 2020. Phyllachora maydis ascospore release and germination from overwintered corn residue. Plant Health Prog. 21:26-30.

Hansen, J., Davison, D., Jones, D., and Sun, X. 2016. Pest alert: Phyllachora maydis, corn tar spot. FDACS-P-02077. Florida Department of Agriculture and Consumer Services Division of Plant Industry, Gainesville, FL.

Hartman, G. L., and Haudenshield, J. S. 2009. Movement of Phakopsora pachyrhizi (soybean rust) spores by non-conventional means. Eur. J. Plant Pathol. 123:225-228. doi: $10.1007 / \mathrm{s} 10658-008-9352-8$. 
Hershman, D. E., Vincelli, P., and Kaiser, C. A. 2011. Foliar fungicide use in corn and soybeans. University of Kentucky Plant Pathology Fact Sheet. 1:9.

Hock, J., Dittrich, U., Renfro, B. L., and Kranz, J. 1992. Sequential development of pathogens in the maize tarspot disease complex. Mycopathologia 117:157-161.

Hock, J., Kranz, J., and Renfo, B. L. 1995. Studies on the epidemiology of the tar spot disease complex of maize in Mexico. Plant Path. 44:490-502.

Hock, J., Kranz, J., and Renfro, B. 1989. El complejo "mancha de asfalto" de maiz: Su distribuccion geografica, requisites ambientales e importancia economica en Mexico. Rev. Mex. Fitopatol. 7:129-135.

Huber, D., and Haneklaus, S. 2007. Managing nutrition to control plant disease. Landbauforsch. Völkenrode 57:313-322.

ipmPIPE. 2020. https://corn.ipmpipe.org/tarspot/.

Jeschke, M. 2019. Tar spot in corn in the Midwestern U.S. Pioneer Crop Insights. https://www.pioneer.com/content/dam/dpagco/pioneer/na/ca/en/files/general-resources/ Agronomy-Sciences-Research-Summary-2019.pdf.

Kleczewski, N. M., and Bowman, N. D. 2021. An observation of corn tar spot dispersal from agricultural fields to an isolated urban plot. Plant Health Prog. 22:69-71. doi: 10.1094/PHP-10-20-0082-BR.

Kleczewski, N. M., Chilvers, M. I., Mueller, D. S., Plewa, D., Robertson, A. E., Smith, D. L., and Telenko, D. E. P. 2019a. Corn disease management: Tar spot. CPN 2012-W. Crop Protection Network.

Kleczewski, N. M., Donnelly, J., and Higgins, R. 2019b. Phyllachora maydis, causal agent of tar spot on corn, can overwinter in northern Illinois. Plant Health Prog. 20:178. doi: 10.1094/PHP-04-19-0030-BR.

Kleczewski, N. M., Plewa, D. E., Bissonnette, K. M., Bowman, N. D., Byrne, J. M., LaForest, J., Dalla-Lana, F., Malvick, D. K., Mueller, D. S., Chilvers, M. I., Paul, P. A., Raid, R. N., Robertson, A. E., Ruhl, G. E., Smith, D. L., and Telenko, D. E. P. 2020. Documenting the establishment, spread, and severity of Phyllachora maydis on corn, in the United States. J. Integr. Pest Manag. 11:14. doi: 10.1093/jipm/pmaa012.

Kreitlow, K. W., Lefebvre, C. L., Presley, J. T., and Zaumeyer, W. J. 1961. Diseases that seeds can spread. Pages 265-272 in: Seeds: The Year Book of Agriculture. 87th Congress, 1st session, House Document no. 29. U.S. Government Printing Office, Washington, DC.

Liu, L.-J. 1973. Incidence of tar spot disease of corn in Puerto Rico. J. Agric. Univ. P. R. 42:211-216.

Mahuku, G., Chen, J., Shrestha, R., Narro, L. A., Osorio-Guerrero, K. V., Arcos A. L., and $\mathrm{Xu}, \mathrm{Y}$. 2016. Combined linkage and association mapping identifies a major QTL (qRtsc8-1), conferring tar spot complex resistance in maize. Theor. Appl. Genet. 129:1217-1229. doi 10.1007/s00122-016-2698-y.

Mahuku, G., Shrestha, R., and San Vicente, F. 2013. Tar Spot Complex of Maize: Facts and Actions. CIMMYT, Mexico D.F.

Malaguti, G., and Subero, L. J. 1972. Mancha de asfalto del maize. Agron. Trop. 22:443445.

Malvick, D. K., Plewa, D. E., Lara, D., Kleczewski, N. M., Floyd, C. M., and Arenz, B. E. 2020. First report of tar spot of corn caused by Phyllachora maydis in Minnesota. Plant Dis. 104:1865.

Maublanc, A. 1904. Especes Nouvelles de champignons inferieurs. Bull. Soc. Mycol. Fr. 20:72-74.

McCoy, A. G., Romberg, M. K., Zaworski, E. R., Robertson, A. E., Phibbs, A., Hudelson, B. D., Smith, D. L., Beiriger, R. L., Raid, R. N., Byrne, J. M., and Chilvers, M. I. 2018. First report of tar spot on corn (Zea mays) caused by Phyllachora maydis in Florida, Iowa, Michigan, and Wisconsin. Plant Dis. 102:1851. doi: 10.1094/PDIS-02-18-0271PDN.

McCoy, A. G., Roth, M. G., Shay, R., Noel, Z. A., Jayawardana, M. A., Longley, R. W., Bonito, G., and Chilvers, M. I. 2019. Identification of fungal communities within the tar spot complex of corn in Michigan via next-generation sequencing. Phytobiomes J. 3:235-243. doi: 10.1094/PBIOMES-03-19-0017-R.

McGuire, J. U., and Crandall, B. S. 1967. Survey of insect pests and plant diseases of selected food crops of Mexico, Central America and Panama. U.S. Department of Agriculture, International Agricultural Development Service, Washington, DC.

Miller, C. 2016. Tar spot of corn detected for the first time in Florida. University of Florida/Institute of Food and Agricultural Sciences, Palm Beach County Cooperative Extension Service Department, West Palm Beach, FL. https:/discover.pbcgov.org/ coextension/agriculture/pdf/Tar\%20Spot\%20of\%20Corn.pdf. Accessed November 15, 2020. 
Mottaleb, K. A., Loladze, A., Sonder, K., Kruseman, G., and San Vicente, F. 2019. Threats of tar spot complex disease of maize in the United States of America and its global consequences. Mitig. Adapt. Strateg. Glob. Chang. 24:281-300.

Mueller, D. S., Wise, K. A., and Sisson, A. J. 2021. Corn disease loss estimates from the United States and Onatrio, Canada - 2020. CPN-2007-20. Crop Protection Network. Published March 18, 2021. doi: 10.31274/cpn-20210324-0.

Mueller, D. S., Wise, K. A., Sisson, A. J., Allen, T. W., Bergstrom, G. C., Bissonnette, K. M., Bradley, C. A., Byamukama, E., Chilvers, M. I., Collins, A. A., Esker, P. D., Faske, T. R., Friskop, A. J., Hagan, A. K., Heiniger, R. W., Hollier, C. A., Isakeit, T., Jackson-Ziems, T. A., Jardine, D. J., Kelly, H. M., Kleczewski, N. M., Koehler, A. M., Koenning, S. R., Malvick, D. K., Mehl, H. L., Meyer, R. F., Paul, P. A., Peltier, A. J., Price, P. P., Robertson, A. E., Roth, G. W., Sikora, E. J., Smith, D. L., Tande, C. A., Telenko, D. E. P., Tenuta, A. U., Thiessen, L. D., and Wiebold, W. J. 2020. Corn yield loss estimates due to diseases in the United States and Ontario, Canada, from 2016 to 2019. Plant Health Prog. 21:238-247.

Müller, E., and Samuels, J. G. 1984. Monographella maydis sp. nov. and its connection to the tar-spot disease of Zea mays. Nova Hedwigia 40:113-121.

Orton, C. R. 1944. Graminicolous species of Phyllachora in North America. Mycologia 36:18-53. doi: 10.1080/00275514.1944.12017527.

Parbery, D. G. 1963. Studies on graminicolous species of Phyllachora Fckl. I. Ascospores Their liberation and germinations. Aust. J. Bot. 11:117-130. doi: 10.1071/BT9630117.

Pereyda-Hernández, J., Hernandez-Morales, J., Sandoval-Islas, J. S., Aranda-Ocampo, S., De León-García de Alba, C., and Gomez-Montiel, S. 2009. Etiology and management of tar spot (Phyllachora maydis Maubl.) of maize in Guerrero State, Mexico. Art Agro. 43:511-519.

ProMED-mail. 2009. Undiagnosed fungus, maize: Guatemala (02): Tar spot. Archive no. 20090420.1491. http://promedmail.org/post/20090420.1491. Accessed November 3, 2020.

Richardson, M. J. 1990. An Annotated List of Seed-Borne Diseases, 4th Ed. International Seed Testing Association, Zurich, Switzerland.

Ríos-Herrera, E. N., Partida-Martinez, L. P., Ochoa-Fuentes, Y. M., Cerna-Chavez, E., Hernanzes-Castillo, F. D., Flores-Olivas, A., Olalde-Portugual, V., and RodriguezGuerra, R. 2016. First report on the presence of Phyllachora sp. in corn crops at Toluca, Estado de Mexico. Am. J. Plant Sci. 7:733-739. doi: 10.4236/ajps.2016.75067.

Rotem, J., and Palti, J. 1969. Irrigation and plant diseases. Annu. Rev. Phytopathol. 7:267288.

Ruhl, G., Romberg, M. K., Bissonnette, S., Plewa, D., Creswell, T., and Wise, K. A. 2016. First report of tar spot on corn caused by Phyllachora maydis in the United States. Plant Dis. 100:1496. doi: 10.1094/PDIS-12-15-1506-PDN.

Schindo, A. 2019. Stay a step ahead of tar spot with Trivapro fungicide. Syngenta US. https:/www.syngenta-us.com/thrive/product/stay-a-step-ahead-of-tar-spot.html.

Shurtleff, M. C. 1982. Compendium of Corn Diseases, 2nd Ed. American Phytopathological Society, St. Paul, MN.

Singh, M. P., Widdicombe, W. D., and Williams, L. A. 2018. Michigan corn hybrids compared. Extension Bulletin E-431. Michigan State University, East Lansing, MI.

Singh, M. P., Widdicombe, W. D., and Williams, L. A. 2020. Michigan corn hybrids compared. Extension Bulletin E-431. Michigan State University, East Lansing, MI.

Smith, D. 2019. Tar spot on my mind. Wisconsin Crop Manager Newsletter. June 20, 2019 https://ipcm.wisc.edu/blog/2019/06/tar-spot-on-my-mind/. Accessed February 17, 2021.

Smith, D. 2020. Wisconsin corn tar spot update - July 29, 2020. https://badgercropdoc.com/ 2020/07/29/wisconsin-corn-tar-spot-update-july-29-2020/. Accessed February 17, 2021.

Stevenson, J. A. 1975. The fungi of Puerto Rico and the American Virgin Islands. Contribution of Reed Herbarium, no. 23, Baltimore, MD.

Stevenson, J. A., and Cardenas, M. 1949. Lista preliminar de los hongos de Bolivia. Lilloa 21:77-134.

Telenko, D. E. P., Chilvers, M. I., Kleczewski, N. M., Smith, D. L., Byrne, A. M., Devillez, P., Diallo, T., Higgins, R., Joos, D., Kohn, K., Lauer, J., Mueller, B., Singh, M. P., Widdicombe, W. D., and Williams, L. A. 2019. How tar spot of corn impacted hybrid yields during the 2018 Midwest epidemic. Crop Protection Network. doi: 10.31274/cpn20190729-002.

Telenko, D. E. P., Chilvers, M., Kleczewski, N., Mueller, D., Plewa, D., Robertson, A., Smith, D., Tenuta, A., and Wise, K. 2020. Tar Spot. CPN 2012-W. Crop Protection Network. doi: 10.31274/cpn-20190620-008.

Tenuta, A. 2020. Corn school: Tackling tar spot in Ontario. https:/www.realagriculture.com/ 2020/10/corn-school-tackling-tar-spot-in-ontario/. Accessed December 17, 2020. 
Turkington, T. K., Kuzyk, A., Dunn, R., McLaren, D., Irvine, B., Clear, R. M., and Patrick, S. K. 2006. Irrigation and plant disease management. Pages 49-52 in: Irrigated Crop Production Update 2006 Conference. Lethbridge, Alberta CA. January 17, 2006.

United States Department of Agriculture - National Agriculture Statistics Service (USDANASS). 2019. Quick Stats https://quickstats.nass.usda.gov/.

Valle-Torres, J., Ross, T. J., Plewa, D., Avellaneda, M.C., Check, J., Chilvers, M. I., Cruz, A. P., Dalla Lana, F., Groves, C., Gongora-Canul, C., Henriquez-Dole, L., Jamann, T., Kleczewski, N. M., Lipps, S., Malvick, D., McCoy, A. G., Mueller, D. S., Paul, P. A., Puerto, C., Schloemer, C., Raid, R. N., Robertson, A., Roggenkamp, E. M., Smith, D. L., Telenko, D. E. P., and Cruz, C. D. 2020. Tar spot: An understudied disease threatening corn production in the Americas. Plant Dis. 104:2541-2550. doi: 10.1094/PDIS-02-200449-FE.

Vieira, R. F., Paula Junior, T. J., Teixeira, H., and Carneiro, J. E de S. 2010. White mold management in common bean by increasing within-row distance between plants. Plant Dis. 94:361-367.

Watson, A. J. 1971. Foreign bacterial and fungus diseases of food, forage, and fiber crops: An annotated list. Agricultural Research Service, U.S. Department of Agriculture Handbook no. 418. U.S. Government Printing Office, Washington, DC.

Wellings, C. R. 2007. Puccinia striiformis in Australia: A review of the incursion, evolution, and adaptation of stripe rust in the period 1979-2006. Aust. J. Agric. Res. 58:567-575. doi: 10.1071/AR07130.

\section{Web Resources}

Tar Spot Web Book: https://cropprotectionnetwork.org/series/tarspot/publications/tar-spot-preface-and-introduction

Identification: Tar Spot of Corn - Michigan State University Field Crop Pathology. https://www.youtube.com/watch?v=lQTW7a_dxLE

Disease Forecast: ipmPIPE (Integrated Pest Management Pest Information Platform for Extension and Education). https://corn.ipmpipe.org/tarspot/

Fungicide Efficacy: Crop Protection Network. https://cropprotectionnetwork.org/resources/publications/fungicide-efficacy-forcontrol-of-corn-diseases

Management: Crop Protection Network. https://crop-protectionnetwork.s3.amazonaws.com/publications/tar-spot-filename-2020-05-12175731.pdf 